\title{
Klavdia Kurvinen
}

\section{Zinaida Lindén ja hänen naishahmonsa}

Zinaida Lindén on kokenut kirjailija. Hänen teoksiaan alettiin julkaista aiemmin kuin kenenkään muun perestroikan jälkeen Suomeen muuttaneen venäläisen. Tällä edelläkävijyydellä on ollut ratkaiseva merkitys hänen kirjailijanuralleen. Lindénin teoksista kuka hyvänsä Venäjää ja venäläistä kirjallisuutta tunteva löytää jotain kiinnostavaa. Hänen tarinansa ovat erilaisia, mutta kaikilla on yksi yhteinen teema: elämä kotimaan ulkopuolella.

Lindénin kirjojen juonet ovat yksinkertaisia ja realistisia, ja tapahtumat vaikuttavat usein täysin autobiografisilta. Tämä ei kuitenkaan ole koko totuus. Lindénillä on Sergei Dovlatovin tapaan todenmukaisuutta ja dokumentaarista tarkkuutta selvästi vähemmän kuin miltä näyttää, kuten kirjailija itse sanoo. ${ }^{1}$ Hänen mukaansa moni suhtautuu hänen kirjojensa tapahtumiin kuin ne olisivat tosielämästä. Lindénin päähenkilöt eivät kuitenkaan ole hänen kaksoisolentojaan, vaan ainoastaan maanmiehiään. Toki juoneen punoutuu usein tositapahtumia, mutta yleensä niissä on kyse vain todentuntuisesta ilmapiiristä tai vähäpätöisistä yksityiskohdista.

Lindénin elämäntarina on monivaiheinen. Syntymäkaupunki Leningrad on kirjailijalle tärkeä. Siellä hän kävi koulunsa, ja Leningradin yliopiston ruotsin kielen ja kulttuurin laitokselta hän vuonna 1986 valmistui. Jo työskennellessään noihin aikoihin oppaana ja kääntäjänä Lindén kehitteli ajatuksiaan ihmisten ykseydestä ja sovinnosta, omasta panoksestaan yhteisymmärryksen edistämiseksi, minkä parissa hän onkin viimeiset 25 vuotta työskennellyt. Hänen kertomansa tarinat toimivat oppaina kahden maailman välillä, joko kahden maan tai kahden ihmisen. Juuri siitä hän on saanut sysäyksen venäjäntää suomenruotsalaisia kirjailijoita, Claes Anderssonia, Monika Fagerholmia, Kjell Westötä ja Martin Enckelliä.

Kirjallisuuteen Lindén uppoutui jo lapsena. Charles Dickens, Fjodor Dostojevski, Arkadi Avertšenko ja Victor Hugo ovat kirjailijoita, jotka ovat vaikuttaneet hänen maailmankatsomukseensa. Hugon Kurjat hän luki jo kahdeksanvuotiaana, eikä rakkaus kirjallisuuteen ole sittemmin sammunut. Matkaoppaan ja kääntäjän työt tarjosivat Lindénille mahdollisuuksia kertoa tarinoita, ja sieltä hänen tarinankerrontataipumuksensa kumpuaakin. Tarinoita olisi ollut kerrottavaksi vielä senkin jälkeen, kun hän vuonna 1991 muutti Suomeen, mutta ei ollut enää ketään kelle kertoa. Niinpä hän päätti ryhtyä kirjoittamaan. Epäselvää oli vain, kenelle kirjoittaa. 
Zinaida Lindénin oletettu lukija on paljon lukenut, sellainen joka ymmärtää lukuisat viittaukset muihin teoksiin, kulttuureihin ja elokuviin. Hän tuntee myös venäläistä kirjallisuutta ja kulttuuria, jotka yleensä kytkeytyvät tiiviisti tarinoiden juoneen. Koska Lindén kirjoittaa paitsi ruotsiksi myös venäjäksi, ovat hänen lukijansakin erilaisia. Suomalaisia kiinnostaa venäläisten maahanmuuttajien elämä ja kulttuuri, venäläisiä lukijoita taas elämä ulkomailla. Niinpä Lindénin teokset parantavat maiden ja kansojen välistä yhteisymmärrystä. Kirjailija pyrkii toimimaan oppaana kahden maailman välillä.

Lindénin kirjojen päähenkilöt tulevat lähelle lukijaa, koska he ovat realistisia ja poikkeuksellisia. Heidän elämäntarinansa ovat niin tavallisia, että tuntuu kuin heidän esikuvansa olisivat lukijan omasta elämästä. Lindénin henkilöhahmojen kohtalot eivät aina ole traagisia, mutta niihin sekoittuu ikäviä sävyjä, joiden kautta kirjailija leikkii vastakohtaisuuksilla. Esimerkiksi romaanin Monta maata sitten (2013) Galina Dolohova, aivan tavallinen nuori nainen, menettää molemmat vanhempansa. Eikä ainoastaan menetä, vaan isä jää raitiovaunun alle, ja 40 päivää myöhemmin äiti tekee itsemurhan miehensä haudalla. Tilanteen odottamaton traagisuus tekee juonesta realistisemman ja pistää miettimään elämän epävakautta sekä kuolemaa.

Tällaisiin yllättäviin yksityiskohtiin törmää niin Lindénin novelleissa kuin romaaneissakin. Päähenkilöt etsivät jatkuvasti itseään: he ovat eksyksissä ja poukkoilevat ihmisten ja maiden välillä. He joutuvat aina samantapaisiin olosuhteisiin, yleensä joko muuttamaan ulkomaille tai sopeutumaan vieraaseen kulttuuriin. Päähenkilöt ovat kirjailijan aikalaisia ja maanmiehiä, joissa neuvostokausi sekoittuu jälkisosialistisen Venäjän kanssa. Galina Dolohova, Ivan Demidov, Iraida Dalina, kaikki nämä hahmot ovat imeneet itseensä kirjailijan omia piirteitä, kaikki he myös ovat Zinaida Lindén.

Lindén kirjoittaa teostensa naishahmot erityisen huolellisesti. Jokaisen vähäisenkin naishahmon henkilökuva on kiintoisa ja täynnä yllättäviä piirteitä. Yleensä hän on vahva ja itsenäinen nainen, joka ei välitä, mitä muut hänestä ajattelevat. Esimerkiksi romaanin Ennen maanjäristystä (2004) viisi vuotta Japanissa asunut amerikkalainen Ellen on englannin kielen opettaja, joka pitää sumopainista ja tekee aina mitä haluaa, vaikka iäkkäät japanilaiset tämän tuomitsevatkin.

Usein Lindénin naishahmot eivät vastaa niitä piirteitä, joita yhteiskunta pitää naisille luonteenomaisina. Hänen teoksissaan on sellaisia naishahmoja, joita heidän omissakin yhteisöissään pidetään epätavallisina. Lindénin kaikissa kirjoissa sukupuoliroolit ovat ilmeinen teema. Ne ovat erityisen huomattavasti esillä romaanin Monta maata sitten päähenkilön anopissa, joka neuvostonaiselle epätyypillisesti työskenteli taksinkuljettajana ja osasi tehdä putkitöitä.

Vapaamielisyys ja vapaudenrakkaus ovat Lindénin naishahmojen tärkeimpiä piirteitä. Hänen romaaniensa sankarittaret suhtautuvat yleensä kielteisesti Venäjän vallanneeseen patriarkaattiin eivätkä halua palvoa miehiään ja alistua näiden valtaan. Feminis- 
tinen teema alkaa ja kehittyy romaaneissa Monta maata sitten ja Ennen maanjäristystä. On syytä mainita, että kyse ei kuitenkaan ole mistään radikaalista feminismistä, jossa kaikki miehet tarkoituksella alistaisivat naisia sekä uusintaisivat alistamisen ja kontrollin mekanismeja. Nyky-Venäjällä feminismistä on tullut kielteinen käsite, ja monet sekoittavat feminismin lesbouteen. Lindénin - yleensä venäläiset - naiset eivät ole äärihenkisiä, he vain yrittävät olla miehistä riippumattomia.

On otettava huomioon myös, millaisten kulttuuristen erityispiirteiden ja ideologioiden ympäröimä nainen on. Lindénin naispäähenkilöt ovat usein hänen maanmiehiään, neuvostoaikana kasvaneita naisia, jotka ovat imeneet itseensä niin neuvostoliittolaista kuin venäläistäkin ideologiaa ja kulttuuria. Myös eurooppalainen, tässä tapauksessa suomenruotsalainen, kulttuuri ja yhteiskunta vaikuttavat suuresti päähenkilöihin, sillä ne ovat vaikuttaneet itse kirjailijaan. On mainittava myös Japani, jonka kulttuurin ja perinteet Lindén hyvin tuntee asuttuaan siellä vuodet 1999-2000.

Itseironia ja huumori ovat Lindénin päḧhenkilöille tyypillisiä piirteitä, sillä ilman niitä elämä vieraassa maassa ei kerta kaikkiaan ole mahdollista. Huumori lähestyy usein absurdin rajoja, kuten novellikokoelmassa Scheherazades sanna historier (2000, ei suom.). Sen päähenkilö on venäläistyttö, joka kehittelee perheelleen uskomattomia tarinoita tapaillessaan arabitaustaista miestä, jota vanhemmat eivät ikimaailmassa hyväksyisi.

Lindénin naishahmot ovat yleensä vaatimattomia mutta poikkeuksellisia naisia. Ulkonäöllään he eivät kerää katseita. Romaanissa Ennen maanjäristystä yksikään nainen, jota kohtaan miespäähenkilö Ivan Demidovilla on tunteita, ei vastaa yleisiä kauneusihanteita. Ivanin vaimo kuvaillaan vartaloltaan pitkäksi ja tavalliseksi sekä kasvoiltaan karkeaksi ja ankaraksi. Yksi häntä kiinnostavista naisista, Manana, tuo muodottomine ylipainoisine vartaloineen Ivanin mieleen naaraskarhun, joka on kuitenkin puhdas ja koskematon kuin vuoripuro.

Myös sattumalla ja odottamattomuudella on Lindénin kirjoissa suuri merkitys, sillä ne tekevät hänen tarinoistaan yhä realistisempia. Romaanin Ennen maanjäristystä päähenkilöt tapaavat sattumalta junassa. Yhtä odottamattomasti romaanin Monta maata sitten naispäähenkilö tutustuu Neva-jokea katsellessaan tulevaan mieheensä, joka on poistunut häiden melskeistä hetkeksi raikasta ilmaa hengittämään. Merkittävät tarinat voivat alkaa tällaisista pienistä ja merkityksettömiltä näyttävistä tilanteista niin Lindénin teoksissa kuin jokapäiväisessä elämässämmekin.

Päähenkilöt tuntuvat jäävän vieraiksi sille yhteiskunnalle, johon ovat päätyneet ja johon yrittävät sopeutua. Maassa voi todellakin elää tunnustamatta kaikkia sen kulttuurin erityispiirteitä. Niinpä voi sanoa, että melkein kaikki Lindénin luomat päähenkilöt ovat ulkopuolisia, vieraita ja toisia, vaikka he ovatkin osa perhettään ja yhteiskuntaa. Päähenkilöt hakevat paikkaansa uudessa yhteiskunnassa, jossa he usein ovat eksyksissä. 
He eivät kuitenkaan menetä henkisiä voimavarojaan, vaan sopeutuvat ja jatkavat elämäänsä erilaisista esteistä huolimatta.

Tällainen oman paikan hakeminen tuntuu sopivan kirjailijan omaan elämäntarinaan. Muutettuaan vuonna 1991 Suomeen Lindén ei hyvästä ruotsin kielen taidostaan huolimatta löytänyt kääntäjän töitä, mikä ajoi hänet luovan työn pariin. Kirjailijan omasta mielestä hänen ensimmäinen novellikokoelmansa ei kuitenkaan ollut kovin hyvä, vaikka se saikin Svenska Litteratursällskapetin palkinnon. Hän kuitenkin jatkoi kirjoittamista kehittyen siinä, ja vuonna 2004 julkaistiin hänen ensimmäinen täyspitkä romaaninsa Ennen maanjäristystä, joka toi Lindénille ensimmäisenä ulkomaalaissyntyisenä kirjailijana Runeberg-palkinnon.

Lindénin kirjoja julkaistaan myös Venäjällä. Pietarin kirjailijaliiton jäsenenä hän pitää tiiviisti yhteyttä pietarilaisiin kirjailijoihin. Kaikkien kolmen romaanin lisäksi hänen novellikokoelmiaan on julkaistu venäjäksi. Kirjailijan omien sanojen mukaan hänen tekstiinsä vaikuttaa se, että hän kirjoittaa sekä venäjäksi että ruotsiksi. Tilanteesta riippuen jotkin asiat syntyvät suoraan ruotsiksi, toiset taas ensin venäjäksi. Sen vuoksi teoksen venäjän- ja ruotsinkielisissä versioissa voi olla joitakin eroja.

Zinaida Lindén on ennen kaikkea kertoja, jonka teoksista välittyy lähikosketus päähenkilöihin. Ensimmäisen ja kolmannen persoonan kerronta vaihtelee, mistä syntyy vaikutelma kuin kirjailija seisoisi päähenkilönsä olkapään takana kuiskien tälle mitä tehdä ja tietäen miten tarina jatkuu. Hän kuitenkin jättää lähes aina lopun avoimeksi. Avoimuus ja keskeneräisyys tarjoavat kirjailijan itsensä mukaan toivon uudesta alusta.

\section{Viitteet}

${ }^{1}$ Kirjoitus perustuu kirjoittajan 11.4.2016 tekemään Zinaida Lindénin haastatteluun. venäjästä suomentanut Mika Perkiömäki 